\title{
Conventional Versus Endoscopic Assisted Septoplasty for Management of Severe Nasal Septal Deviation
}

\author{
MARAM A. HASABALLAH, M.Sc.; ABU BAKR S. BEHERY, M.D.; OSAMA A. AL-BIRMAWY, M.D. and \\ MAGDY E. SAAFAN, M.D.
}

The Department of Otolaryngology, Faculty of Medicine, Tanta University, Tanta, Egypt

\begin{abstract}
Background: Endoscopic septoplasty is an attractive alternative to the traditional septoplasty. It ensures the minimum dissection of the tissue with less postoperative complications.

Aim of Work: The aim of this work was to compare the efficacy of the conventional and the endoscopic assisted septoplasty in the management of cases with severe septal deviation.

Patients and Methods: 60 patients with severe symptomatic deviated nasal septum, presented to the Otorhinolaryngology outpatient clinic at Tanta University Hospitals divided into two equal groups: Group A included 30 patients underwent endoscopic septoplasty and group B included 30 patients underwent traditional septoplasty. All participants evaluated regarding the nasal obstruction improvement, and the degree of the improvement, the accompanying symptoms and any complications.

Results: There was a significant difference between both groups in duration of surgery, the intraoperative blood loss. In this study, the difference of the endoscopic group as compared to the conventional group was statistically insignificant regarding either early post-operative complications or in nasal synechiae development, pain, septal hematoma, septal perforation, or CSF leakage or in the intraoperative flap. The pre-operative nose score comparative evaluation revealed that all patients of both groups reported a severe problem in all parameters (nasal congestion and stuffiness, nasal blockage or obstruction, trouble breath in through the nose, trouble sleeping, and inability to get enough air through the nose during exercise or exertion. No statistically significant differences were detected between both groups.
\end{abstract}

Conclusion: We concluded that, endoscopic septoplasty is superior to traditional septoplasty with better result and less complication.

Key Words: Endoscopic - Septoplasty - Septum - Nasal obstruction.

Correspondence to: Dr. Maram A. Hasaballah, The Department of Otolaryngology, Tanta University, Tanta, Egypt

\section{Introduction}

A significantly deviated nasal septum cause nasal obstruction, prompt epistaxis, sinusitis, obstructive sleep apnea and headaches [1]. Numerous surgical techniques are available but each surgical procedure has its limitations and cannot deal with all the variants of the deformities of the nasal septum [2] Endoscopic septoplasty is an attractive alternative to the traditional septoplasty. It ensures the minimum dissection of the tissue with less postoperative complications [3]. The aim of this work was to compare the efficacy of the conventional and the endoscopic assisted septoplasty in the management of cases with severe septal deviation.

\section{Patients and Methods}

This study was included 60 patients older than 18 years, from both sex with severe symptomatic deviated nasal septum, presented to the Otorhinolaryngology outpatient clinic at Tanta University Hospitals between January 2017 and December 2017.

Approval for the study was obtained from both the Institutional and the Regional Ethical Committees. Patients aged less than 18 years or more than 60 years, patient with nasal polyposis or nasal tumors, patients with sinusitis not responding to medical treatment, patients with craniofacial alterations or congenital malformation and patients with associated co-morbidity (diabetes mellitus, hepatitis, renal disorders, hypertension, cardiac diseases, bleeding disorder, anemia, malnutrition) were excluded from the study.

A detailed explanation of the procedure and the purpose of the study was offered to each patient. An informed written consent was obtained from all patients. All included patients were subjected 
to detailed history taking regarding the nasal obstruction which was the main complaint of all patients with emphasis on onset, course, and duration of the nasal obstruction, the side of the obstruction, postnasal discharge, epistaxis, hyposmia, past history of using nasal decongestant drops or any other medical treatment and its effect.

Meticulous preoperative examination was done by anterior rhinoscopy. Nasal patency examination and diagnostic nasal endoscopy for all patients was conducted to meticulously assess the type and severity of the septal. CT scans of the paranasal sinuses was done only when chronic sinusitis was suspected. Pre-operative routine investigations as complete blood count, bleeding time, coagulation time, prothrombin time, partial prothrombin time, random blood sugar, liver enzyme, serum creatinine, ECG, and chest X-ray were done.

The patients were randomly divided into two equal groups: Group A included 30 patients underwent endoscopic septoplasty and group B included 30 patients underwent traditional septoplasty.

\section{Technique of endoscopic septoplasty:}

Using the endoscope, submucosal infiltration of the nasal septum was done. An incision was performed on the left side of the septum using number 15.blade.

After the mucosal incision, a mucoperichondrial flap was dissected, at the proper cleavage plane to minimize bleeding, using a Cottle elevator. A suction elevator could also be used as an alternative dissecting instrument to simultaneously clear any blood from the field of view during the flap elevation. Further dissection was done using 0 degrees Karl Storz nasal endoscopy ( $4 \mathrm{~mm}$ ) held in the left hand, keeping the tip of the endoscope between the mucoperichondrial flap and the septal cartilage.

The septal cartilage was then incised posterior to the mucosal incision. The dissection of the contralateral mucoperichondrial flap was then performed Fig. (1). In cases with deviated maxillary crest,the flap was dissected off the maxillary crest, and the vomer,andthe deviated parts were re- movedusing a gouge and a hammer under endoscopic vision.

The duration of the operation and the amount of blood loss were recorded for each case. All patients were kept under observation in the hospital for 24 for any sign of nasal bleeding. Antibiotics and oral anti-inflammatory were prescribed for all cases. After removal of nasal packs, patients were discharged and were kept on a regimen of alkaline nasal douche for one month. The nasal splint, if used, was removed after one week.

All patients were evaluated post-operatively, once weekly for the first month then every 2 weeks for 3 months, then monthly till 6 months, regarding the nasal obstruction whether improved or not, and the degree of the improvement (no, mild, moderate, severe), also, the accompanying symptoms as a headache, snoring, postnasal discharge, epistaxis and hyposmia, whether disappeared or still persistent. Patients were checked out for any complications such as pain, discomfort, smelling a bad odor, epistaxis, or any new symptoms that were not present pre-operatively. They were also examined using nasal endoscopy for any residual deformity of nasal septum or spurs, septal perforation, septal hematoma, nasal adhesion. All patients were subjected to a subjective evaluation of life quality and effectiveness of the treatment of nasal obstruction using the NOSE scale [4] before and 3 months after surgery (Table 1 ).

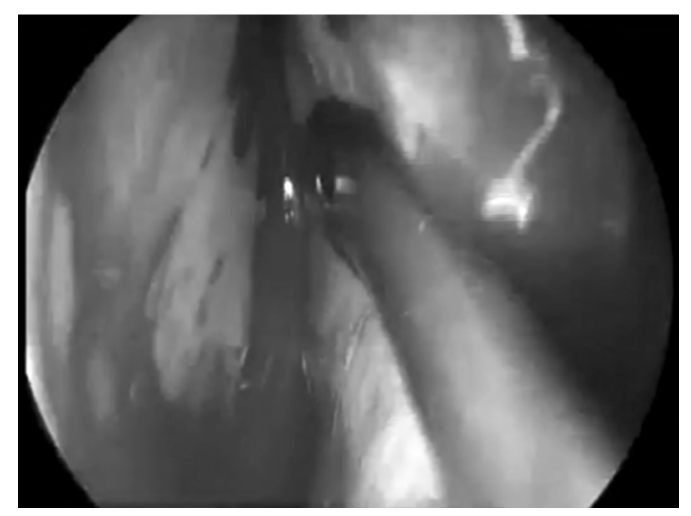

Fig. (1): Suction elevator is used for flap elevation on the left side.

Table (1): Final version of the NOSE instrument. (The NOSE Scale 2003, the American Academy of Otolaryngology-Head and Neck Surgery Foundation.

\begin{tabular}{|c|c|c|c|c|c|}
\hline Symptoms & $\begin{array}{c}\text { Not a } \\
\text { problem }\end{array}$ & $\begin{array}{l}\text { Very mild } \\
\text { problem }\end{array}$ & $\begin{array}{c}\text { Moderate } \\
\text { problem }\end{array}$ & $\begin{array}{c}\text { Fairly bad } \\
\text { problem }\end{array}$ & $\begin{array}{c}\text { Severe } \\
\text { problem }\end{array}$ \\
\hline - Nasal congestion or stuffiness. & 0 & 1 & 2 & 3 & 4 \\
\hline - Nasal blockage or obstruction. & 0 & 1 & 2 & 3 & 4 \\
\hline - Trouble breathing through my nose. & 0 & 1 & 2 & 3 & 4 \\
\hline - Trouble sleeping. & 0 & 1 & 2 & 3 & 4 \\
\hline - Unable to get enough air through my nose during exercise or exertion. & 0 & 1 & 2 & 3 & 4 \\
\hline
\end{tabular}




\section{Results}

The demographic data of the study was shown in (Table 2), there was no statistically significant difference in age and sex of both ( $p 0.639$ and 0.152 , respectively).

Types of the septal deformity showed no statistically significant difference between both groups, $(p 0.143)$. In group A: 9 (30\%) patients had a Broadly deviated septum, whereas $12(40 \%)$ patients had an isolated spur deviation, and 9 (30\%) patients had more than one type of septal deformity. In group B: $12(40 \%)$ patients had a Broadly deviated septum, whereas $9(30 \%)$ patients had an isolated spur deviation, and $9(30 \%)$ patients had more than one type of septal deformity.

The duration of the operation was variable in group A as follow, 20 minutes for the isolated septal spur, up to 50 minutes in the broadly deviated septum and multiple septal deformities with a mean of $39.75 \pm 9.24$ minutes. But in group $B$, it ranged between 35 and 65 minutes with a mean of $52.25 \pm$ 9.10 minutes. There was a significant difference between both groups $(p 0,001)$. Regarding the intraoperative blood loss, there was a high statistically significant difference between both groups $(p 0,001)$. The amount of the intraoperative blood loss in group A was $25-65 \mathrm{ml}$ with mean value of $41.50 \pm 11.7$ while in group B was $45-90 \mathrm{ml}$ with mean value of $70.75 \pm 15.06$. All cases of both groups (100\%) had a post-operative nasal packing. The intra operative flap tear was managed with insertion of a septal splint.

In group A, 3 patients (10\%) had mild epistaxis upon removal of the pack, one week postoperatively, 3 patients (10\%) experienced mild pain and discomfort, 2 patients $(6.7 \%)$ smelled a bad odor, and 2 patients $(6.7 \%)$ developed synechiae. No septal hematoma, septal perforation, or CSF leakage was reported while in group B, 7 patients (23.3\%) had mild epistaxis upon removal of the pack, however. One week post-operatively, 7 patients $(23.3 \%)$ experienced mild pain and discomfort, 5 patients $(16.7 \%)$ smelled a bad odor caused by nasal infection and crustations, 5 patients $(16.7 \%)$ developed synechiae, one case (3.3\%) manifested septal hematoma, and one case (3.3\%) developed septal perforation. CSF leakage was not reported. The difference between both groups was statistically insignificant.

Six months post-operatively, group A included 2 patients $(6.7 \%)$ with persistent posterior deviation, 2 patients $(6.7 \%)$ with nasal crustations. Persistent contact with the turbinate, or persistent spur, nasal synechiae, and septal hematoma were not detected in this group. While group B included 8 patients (26.7\%) with persistent posterior deviation, 5 patients $(16.7 \%)$ with persistent spur, 4 patients $(13.3 \%)$ with nasal crustations, 6 patients $(20 \%)$ with persistent contact with turbinate, 2 patients $(6.7 \%)$ with nasal synechiae, and one patient $(3.3 \%)$ with septal perforation. The septal hematoma was not reported. There were no statistically significant differences between both groups regarding nasal endoscopic findings after 6 months Fig. (1).

The pre-operative nose score comparative evaluation revealed that all patients of both groups reported a severe problem in all parameters (nasal congestion and stuffiness, nasal blockage or obstruction, trouble breath in through the nose, trouble sleeping, and inability to get enough air through the nose during exercise or exertion. No statistically significant differences were detected between both groups.

Assessment of the patients' quality of life after 3 months following each operation using the preoperative nose score comparative revealed the following; in group A, Nasal congestion or stuffiness was not a problem in 25 patients $(83.3 \%)$, very mild problem in 4 patients $(13.3 \%)$, moderate problem in 1 patients (3.3\%). In group B; Nasal congestion was not a problem in 24 patients $(80 \%)$, a very mild problem in 2 patients $(6.7 \%)$, and moderate problem in 4 patients $(13.3 \%)$. The difference between both groups was significant ( $p$ $0.06)$. Regarding the post-operative nasal blockage, in group $\mathrm{A}$, the nasal blockage was not a problem in 24 patients $(80 \%)$, a very mild problem in 4 patients (13.3\%), a moderate problem in 2 patients $(6.7 \%)$. While in group B; nasal blockage was not a problem in 24 patients $(80 \%)$, a very mild problem in 4 patients $(13.3 \%)$, and moderate problem in 2 patients $(6.7 \%)$. The difference between both groups was significant $(p 0.025)$. Regarding breathing through the nose, in group A, breathing through the nose was not a problem in 24 patients $(80 \%)$, a very mild problem in 4 patients $(13.3 \%)$, a moderate problem in 2 patients $(6.7 \%)$. While in group $\mathrm{B}$; breathing through the nose was not a problem in 10 patients $(33.3 \%)$, a very mild problem in 16 patients $(53.3 \%)$, and moderate problem in 4 patients $(13.3 \%)$. The difference between both groups was significant ( $p$ 0.045). Regarding the trouble sleeping, in group A, trouble sleeping was not a problem in 24 patients $(80 \%)$, a very mild problem in 4 patients $(13.3 \%)$, a bad problem in 2 patients $(6.7 \%)$. While in group B; trouble sleeping was not a problem in 10 patients $(33.3 \%)$, a very mild 
problem in 12 patients (40\%), a moderate problem in 6 patients $(20 \%)$, and bad problem in 2 patients $(6.7 \%)$. The difference between both groups was significant $(p 0.042)$. Regarding the ability to get enough air through the nose during exercise or exertion, in group A, it was not a problem in 26 patients $(86 \%)$, a very mild problem in 2 patients $(6.7 \%)$, a bad problem in 2 patients $(6.7 \%)$. While in group B; it was not a problem in 10 patients (33.3\%), a very mild problem in 8 patients $(26.7 \%)$, moderate problem in 8 patients $(26.7 \%)$, bad problem in 2 patients $(6.7 \%)$, and severe problem in 2 patients $(6.7 \%)$. The difference between both groups was significant $(p 0.023)$.

Table (2): Age \& sex distribution of the study cases.

\begin{tabular}{llll}
\hline Sex distribution & $\begin{array}{c}\text { Endoscopic } \\
\text { septoplasty }\end{array}$ & $\begin{array}{c}\text { Conventional } \\
\text { septoplasty }\end{array}$ & Total \\
\hline $\begin{array}{lll}\text { Age (years): } \\
\text { Range }\end{array}$ & $19-39$ & $18-36$ & \\
Mean \pm SD & $29.63 \pm 3.25$ & $30.24 \pm 4.62$ & \\
t-test & & 1.253 & \\
p-value & & 0.639 & \\
Male: & & & 29 \\
$\mathrm{~N}$ & 17 & 12 & $48.3 \%$ \\
$\%$ & $56.7 \%$ & $40.0 \%$ & 31 \\
Female: & & & $51.7 \%$ \\
$\mathrm{~N}$ & 13 & 18 & \\
$\%$ & $43.3 \%$ & $60.0 \%$ & $100.0 \%$ \\
Total: & & & \\
$\mathrm{N}$ & 30 & 30 & \\
$\%$ & $100.0 \%$ & $100.0 \%$ & \\
Chi-square: & & & \\
$\chi{ }^{2}$ & & $0.152 *$ & \\
p-value & & & \\
\hline
\end{tabular}

Table (3): Types of the septal deformity at presentation in both groups identified by the endoscopic examination.

\begin{tabular}{llll}
\hline Types of & \multicolumn{3}{c}{ Endoscopic Conventional } \\
septal deformity & septoplasty & septoplasty & \\
\hline Septal spur: & & & \\
$\mathrm{N}$ & 12 & 9 & 21 \\
$\%$ & $40.0 \%$ & $30.0 \%$ & $35.0 \%$ \\
Broadly deviated septum: & & & \\
$\quad \mathrm{N}$ & 9 & 12 & 21 \\
$\%$ & $30.0 \%$ & $40.0 \%$ & $35.0 \%$ \\
Multi-septal deformities: & & & \\
$\mathrm{N}$ & 9 & 9 & 18 \\
$\%$ & $30.0 \%$ & $30.0 \%$ & $30.0 \%$ \\
Total: & & & \\
$\mathrm{N}$ & 30 & 30 & 60 \\
$\%$ & $100.0 \%$ & $100.0 \%$ & $100.0 \%$ \\
Chi-square: & & & \\
$\chi^{2}$ & & $0.241 *$ & \\
p & & $0.143 *$ & \\
\hline
\end{tabular}

Table (4): Duration of the operation, blood loss, nasal packing, intraoperative flap tear and septal splinting.

\begin{tabular}{|c|c|c|c|c|c|c|}
\hline $\begin{array}{l}\text { Operative } \\
\text { details }\end{array}$ & \multicolumn{4}{|c|}{$\begin{array}{l}\text { Endoscopic Conventional } \\
\text { septoplasty septoplasty }\end{array}$} & $\begin{array}{l}t- \\
\text { test }\end{array}$ & $\begin{array}{c}p- \\
\text { value }\end{array}$ \\
\hline \multicolumn{7}{|l|}{ Duration: } \\
\hline Range & \multicolumn{2}{|c|}{$20-50$} & \multicolumn{2}{|l|}{$35-65$} & 15.25 & $0.001 \%$ \\
\hline Mean \pm SD & \multicolumn{2}{|c|}{$39.75 \pm 9.24$} & \multicolumn{2}{|c|}{$52.25 \pm 9.10$} & & \\
\hline \multicolumn{7}{|l|}{ Blood loss: } \\
\hline Range & \multicolumn{2}{|c|}{$25-65$} & \multicolumn{2}{|c|}{$45-90$} & 46.325 & $0.001 \ddagger$ \\
\hline Mean \pm SD & \multicolumn{2}{|c|}{$41.50 \pm 11.7$} & \multicolumn{2}{|c|}{$70.75 \pm 15.06$} & & \\
\hline \multicolumn{7}{|l|}{ Nasal packing: } \\
\hline Yes & 30 & 100 & 30 & 100 & & \\
\hline No & - & - & - & - & & - \\
\hline \multicolumn{7}{|l|}{ Intraoperative } \\
\hline \multicolumn{7}{|l|}{ flap tear: } \\
\hline Yes & 5 & 16.7 & 10 & 33.3 & 2.222 & $0.136^{*}$ \\
\hline No & 25 & 83.3 & 20 & 66.7 & & \\
\hline \multicolumn{7}{|l|}{ Septal splinting: } \\
\hline Yes & 5 & 16.7 & 10 & 33.3 & 2.222 & $0.136^{*}$ \\
\hline No & 25 & 83.3 & 20 & 66.7 & & \\
\hline
\end{tabular}

Table (5): Early post-operative complications during the first week.

\begin{tabular}{llllllll}
\hline & \multicolumn{2}{c}{$\begin{array}{l}\text { Endoscopic } \\
\text { Complications }\end{array}$} & $\begin{array}{c}\text { Conventional } \\
\text { septoplasty }\end{array}$ & \multicolumn{2}{c}{ septoplasty } & $\begin{array}{c}\text { Chi- } \\
\text { square }\end{array}$ & $\begin{array}{c}p \text { - } \\
\text { value }\end{array}$ \\
\cline { 2 - 5 } & $\mathrm{N}$ & $\%$ & $\mathrm{~N}$ & $\%$ & & \\
\hline $\begin{array}{l}\text { Epistaxis: } \\
\text { Yes }\end{array}$ & 3 & 10 & 7 & 23.3 & 1.920 & $0.166^{*}$ \\
No & 27 & 90 & 23 & 76.7 & & \\
Synechiae: & & & & & & \\
Yes & 2 & 6.7 & 5 & 16.7 & 1.456 & $0.228^{*}$ \\
No & 28 & 93.3 & 25 & 83.3 & &
\end{tabular}

Mildpain and

discomfort:

$\begin{array}{lllllll}\text { Yes } & 3 & 10 & 7 & 23.3 & 1.920 & 0.166^{*} \\ \text { No } & 27 & 90 & 23 & 76.7 & & \end{array}$

Smell of bad

odor:

$\begin{array}{lllllll}\text { Yes } & 2 & 6.7 & 5 & 16.7 & 1.456 & 0.228^{*} \\ \text { No } & 28 & 93.3 & 25 & 83.3 & & \end{array}$

Septal

hematoma:

\begin{tabular}{lllllll} 
Yes & 0 & 0 & 1 & 3.3 & 1.017 & $0.313^{*}$ \\
No & 30 & 100 & 29 & 96.7 & & \\
CSF leakage: & & & & & & \\
$\quad$ Yes & - & - & - & - & - & - \\
No & 30 & 100 & 30 & 100 & & \\
Perforation: & & & & & & \\
$\quad$ Yes & 0 & 0 & 1 & 3.3 & 1.017 & $0.313^{*}$ \\
No & 30 & 100 & 29 & 96.7 & & \\
\hline
\end{tabular}




\section{Discussion}

Septum deviation is the major cause of nasal obstruction which is the most common symptom in ENT practice [5]. Surgical correction of the deviated nasal septum has been advanced over the years, from the radical removal of both mucosa and cartilage, submucous cartilage resection with preservation of the mucosa, to the modern techniques of septoplasty which were first introduced by Cottle [6]

Regarding the duration of conventional and endoscopic septoplasty. Using the endoscope, the incision was made on the spur itself which markedly reduced the extent of subperichondrial dissection. This resulted in an apparent reduction in the duration of the procedure compared to the conventional septoplasty with a statistically significant difference (p 0.001).

Supporting this study results, Aiyeretal, [7] reported that, regarding cases of isolated spur or limited deviation in the nasal septum, the duration of endoscopic septoplasty was relatively shorter than traditional septoplasty. On the other side, Richtsmeier et al., [8] reported that the average time of limited endoscopic septoplasty was $12 \mathrm{~min}$. Comparatively, the time required for a traditional septoplasty was nearly threefold ( $35 \mathrm{~min})$.

We found an insignificant difference between both groups in the intraoperative flap ( $p$ 0.136). Similar to these results were the results of Kaushik, Vashistha, \& Jain, [9] who reported an intraoperative flap tear in 3 cases (10\%) in the conventional group and 2 cases $(6.67 \%)$ in the endoscopic group with an insignificant difference between both groups. On the contrary, Jain et al., [10] reported flap tear in 15 patients (68\%) during conventional septoplasty and only 1 patient (5\%) during endoscopic septoplasty which was a statistically insignificant difference.

To avoid synechiae formation following the intraoperative flap tears, septal splints were used in this study. Jung et al., [11] support this study regarding that splints should be a routine step in septal surgery. On the contrary, Gctz \& Hwang, [12] reported that placement of splints is unnecessary and should not be considered as a rule neither should be packing.

In this study, at the end of the surgery, the nose was packed with a small pack of merocel for one day to avoid the post-operative bleeding. Beule et al., [13] reported that nasal packing after septoplasty improved post-operative outcomes regarding nasal breathing, recurrence rate, adhesions, and wound healing as it prevented mucosal dryness.

The difference of the endoscopic group as compared to the conventional group was statistically insignificant regarding early post-operative complications ( $p$ 0.166). Similar results were obtained by Kaushik et al., [9] who reported more epistaxis cases in the conventional group than the endoscopic group with a statistically insignificant difference. On the other hand, Suligavi et al., [14] reported a statistically significant difference between the conventional group [ 13 cases (26\%)] and the endoscopic group [7 cases (14\%)].

In this study, the differences were statistically insignificant in nasal synechiae development, pain, septal hematoma, septal perforation, or CSF leakage ( $p 0,228,0.166,0.228, \& 0.313$ respectively). Results of this study agree with Bothra \& Mathur, [15] who did not detect statistically significant differences in the reported immediate post-operative complications although, there was an obvious clinical difference between the two groups in favor of the endoscopic group. While Sindwani \& Wright, [16]reported a zero incidence of complications in their series of limited endoscopic approach for contact point lesions, however, their population size was only 13 .

Regarding this study, a statistically significant difference was reported regarding the residual contact between the septum and the turbinate. The results of this study agree with the results of Jain et al., [10] regarding persistent posterior and spur deviations and synechiae formation who reported statistically significant differences between both groups. While the differences in the persistent septal turbinate contact were statistically insignificant. On the other side, the conventional group experienced a persistent posterior deviation (23\%), $13 \%$ had a persistent spur deviation, $13 \%$ had a persistent anterior deviation, and $20 \%$ had a persistent septal turbinate contact. Except for the persistent anterior deviation, all other complications showed statistically significant differences. On the contrary, Kaushik et al., [9] reported less posterior and spur deviations in the endoscopic group than the conventional group, but their results were statistically insignificant.

\section{Conclusion:}

We concluded that, endoscopic septoplasty is superior to traditional septoplasty because it permits accurate identification of the pathology, it is more effective in eliminating the septal turbinate contact, it guarantees better visualization, it minimizes the 
dissection in cases of isolated spur deviations, it allows an accurate identification of the cleavage planes for flap elevation especially in revision and in post-traumatic deviations, which minimize the risk of tears, perforations, and the intraoperative bleeding. However, there are some drawbacks of endoscopic septoplasty as loss of the binocular vision, the surgeon cannot use him both hands at the same time, the frequent need for tip cleaning.

\section{References}

1- PANNU K.K., CHADHA S. and PREET KAUR I.: Evaluation of benefits of nasal septal surgery on nasal symptoms and general health. Indian J. Otolaryngol., 61 (1): 59-65, 2009.

2- MANDOUR Z.M.: What nasal endoscope adds in septoplasty. Egyptian Journal of Ear, Nose, Throat and Allied Sciences, 18 (1): 11-5, 2017.

3- AL-SHEHRI A.M., AMIN H.M. and NECKLAWY A.: Retrospective study of endoscopic nasal septoplasty. Biomed. Res., 24 (3), 2013.

4- STEWART M.G., SMITH T.L., WEAVER E.M., WITSELL D.L., YUEH B., HANNLEY M.T., et al.: Outcomes after nasal septoplasty: Results from the Nasal Obstruction Septoplasty Effectiveness (NOSE) study. Otolaryng. Head Neck, 130 (3): 283-90, 2004.

5- DINIS P.B. and HAIDER H.: Septoplasty: Long-term evaluation of results. Am. J. Otolaryng., 23 (2): 85-90, 2002.

6- GUPTA N.: Endoscopic septoplasty. Indian J. Otolaryngol., 57 (3): 240-3, 2005.
7- AIYER R.G. G.R. and RAVAL J.: Endoscupic septoplasty: A novel technique-A case series of 19 cases. Clinical Rhinology, 2 (3): 11-3, 2009.

8- RICHTSMEIER W.J., CANTRELL H. and RICHTSMEIER W.J.: Limited septoplasty for endoscopic sinus surgery. Otolaryng. Head Neck, 116 (2): 274-7, 1997.

9- KAUSHIK S., VASHISTHA S. and JAIN N.: Endoscopic vs conventional septoplasty: A comparative study. Clin. Rhinol. Int. J., 6: 84, 2013.

10- JAIN L., JAIN M., CHOUHAN A. and HARSHWARDHAN R.: Conventional septoplasty verses endoscopic septoplasty: A comparative study, 2011.

11- JUNG Y.G., HONG J.W., EUN Y.G. and KIM M.G.: Objective usefulness of thin silastic septal splints after septal surgery. Am. J. Rhinol. Allergy, 25 (3): 182-5, 2011.

12- GETZ A.E. and HWANG P.H.: Endoscopic septoplasty. Curr. Opin. Otolaryngo., 16 (1): 26-31, 2008.

13- BEULE A., WEBER R., KAFTAN H. and HOSEMANN W.: Review: Pathophysiology and methodology of nasal packing. Laryngo. Rhino. Otol., 83 (8): 534-51; quiz 536, 2004.

14- SULIGAVI S., DARDE M. and GUTTIGOLI B.: Endoscopic Septoplasty; Advantages And Disadvantages; Clinical Rhinology. Int. J., 3 (1): 27-30, 2010.

15- BOTHRA R. and MATHUR N.: Comparative evaluation of conventional versus endoscopic septoplasty for limited septal deviation and spur. The Journal of Laryngology \& Otology, 123 (7): 737-41, 2009.

16- SINDWANI R. and WRIGHT E.D.: Role of endoscopic septoplasty in the treatment of atypical facial pain. J. Otolaryngo., 32 (2), 2003. 


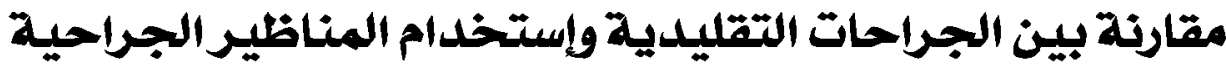

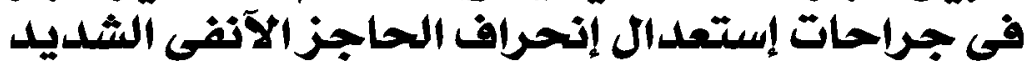

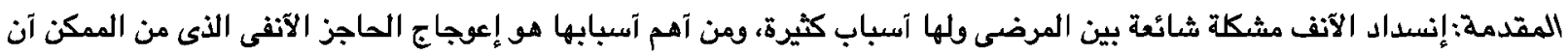

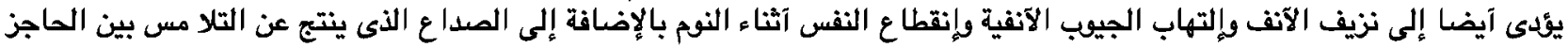
الآنفى وغضى إنغاريف الآنف.

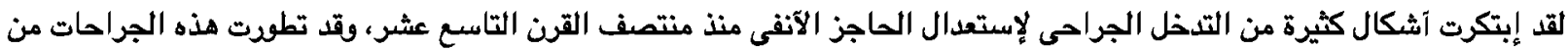
الإزالة الجذرية للجزء المعوح من الحاجز الآنفى تماما، ثم تحولت المحافظة على الفشاء المخاطى للحاجز الآنفى، ثم المحافظة على آكبر جزء التهاء

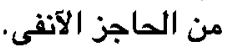

ومن الممكن آن تكون عملية إستعدال الحاجز الآنفى عملية قائمة بذاتها آو آن يتم إجرائها خلال جراحات آخرى كجراحات مناظير الجيوب الآنفية الوظيفية.

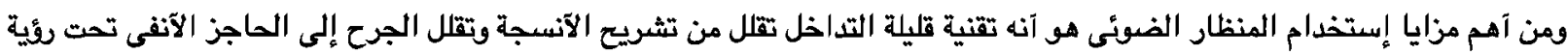

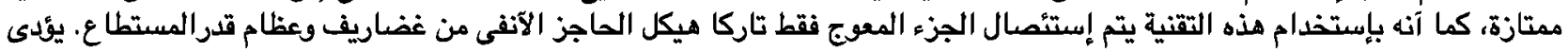

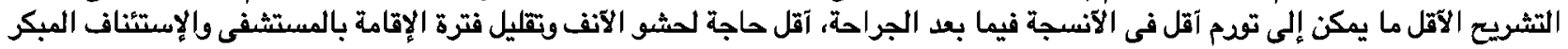

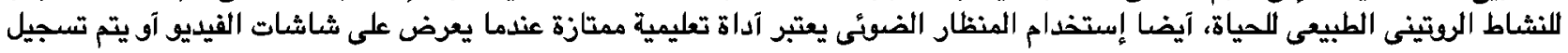

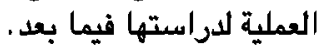

الهدف من البحث: إن دراستتا الهدف منها هو المقارنة بين إجراء عمليات إستعدال الحاجز الآنفى بالمنظار مع غيرها بالطريقة التقليدية دون إستخدام المنظار. طريقة البحث: لقد تم إجراء الدراسة على ـ7 مريض يعانون من إنسداد الآنف الناتج عن إعوجاج الحاجز الآنفى. تم تقسيم المرضى عشوائيا إلى مجموعتين:

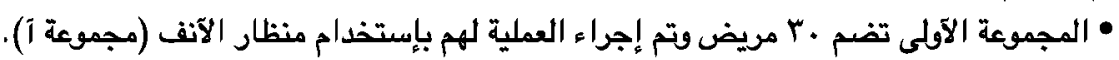

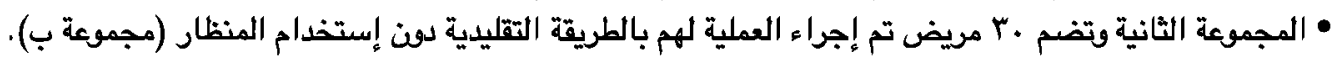

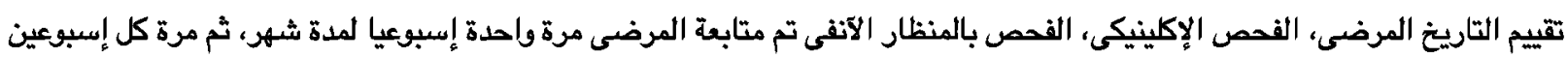

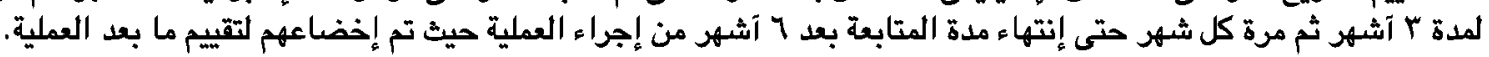

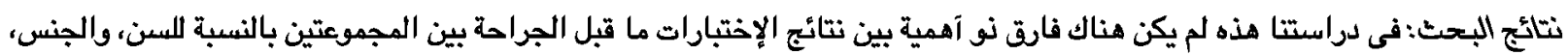

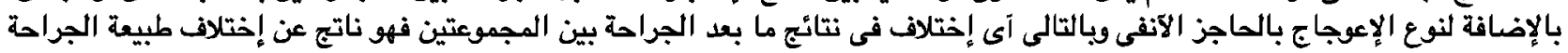
بين المجموعتين.

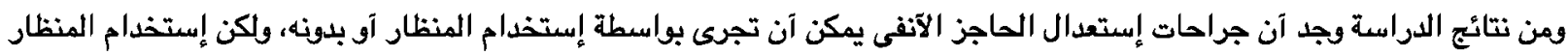

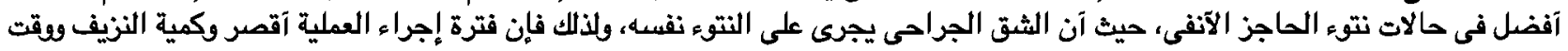

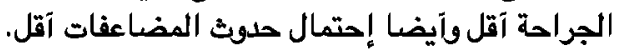
كما إن إستخدام المنظار الآنفى يقلل وجود آى إعوجاج متبقى بعد إجراء العملية خاصة الجزء الخلفى ونتوعات الحاجز الآنفى. كما إن إستخدام المنظار الآنفى يقلل من فرصة حدوث تلامس بين الصاجز الآنفى وغضاريف الآنف. 